\title{
MASTER
}

ORNL/TM-6185

\section{Deposition of Silicon Carbide Coatings on Particles in a Fluidized Bed Using Silane and Tetramethylsilane- A Feasibility Study}

\section{J. I. Federer}

OAK RIDGE NATIONAL LABORATORY OPERATED BY UNION CARBIDE CORPORATION · FOR THE DEPARTMENT OF ENERGY 


\section{DISCLAIMER}

This report was prepared as an account of work sponsored by an agency of the United States Government. Neither the United States Government nor any agency Thereof, nor any of their employees, makes any warranty, express or implied, or assumes any legal liability or responsibility for the accuracy, completeness, or usefulness of any information, apparatus, product, or process disclosed, or represents that its use would not infringe privately owned rights. Reference herein to any specific commercial product, process, or service by trade name, trademark, manufacturer, or otherwise does not necessarily constitute or imply its endorsement, recommendation, or favoring by the United States Government or any agency thereof. The views and opinions of authors expressed herein do not necessarily state or reflect those of the United States Government or any agency thereof. 


\section{DISCLAIMER}

Portions of this document may be illegible in electronic image products. Images are produced from the best available original document. 
Printed in the United States of America. Available from Natinnal Technical Information Service

U.S. Dejpartment of Commcrce

5285 Port Royal Road, Springfield, Virginia 22161

Price: Printed Copy $\$ 4.00$; Microfiche $\$ 3.00$

This report was prepared as an account of work sponsored by an agency of the United States Government. Neither the United States Government nor any agency thereof, nor any of their employees, contractors, subcontractors, or their employees, makes any warranty, express or implied, nor assumes any legal liability or responsibility for any third party's use or the results of such use of any information, apparatus, product or process disclosed in this report, nor represents that its use by such third party would not infringe privately owned rights. 
ORNL/TM-6185

Distribution

Category UC-77

Contract No. W-7405-eng-26

METALS AND CERAMICS DIVISION

HTGR BASE TECHNOLOGY PROGRAM

Fueled Graphite Development

(189a OHOO2)

DEPOSITION OF SILICON CARBIDE COATINGS ON PARTICLES IN A FLUIDIZED BED USING SILANE AND TETRAMETHYLSILANE A FEASIBILITY STUDY

J. I. Federer

Date Published: March 1978

NOTICE This document contains information of a preliminary nature. It is subject tu revislon or coirection and therefore does not represent a final report.

OAK RIDGE NATIONAL LABORATORY

Oak Ridge, Tennessee 37830

operated by

UNION CARBIDE CORPORATION

for the

DEPARTMFNT OF ENERCY 


\section{THIS PAGE}

\section{WAS INTENTIONALLY}

LEFT BLANK 


\section{CONTENTS}

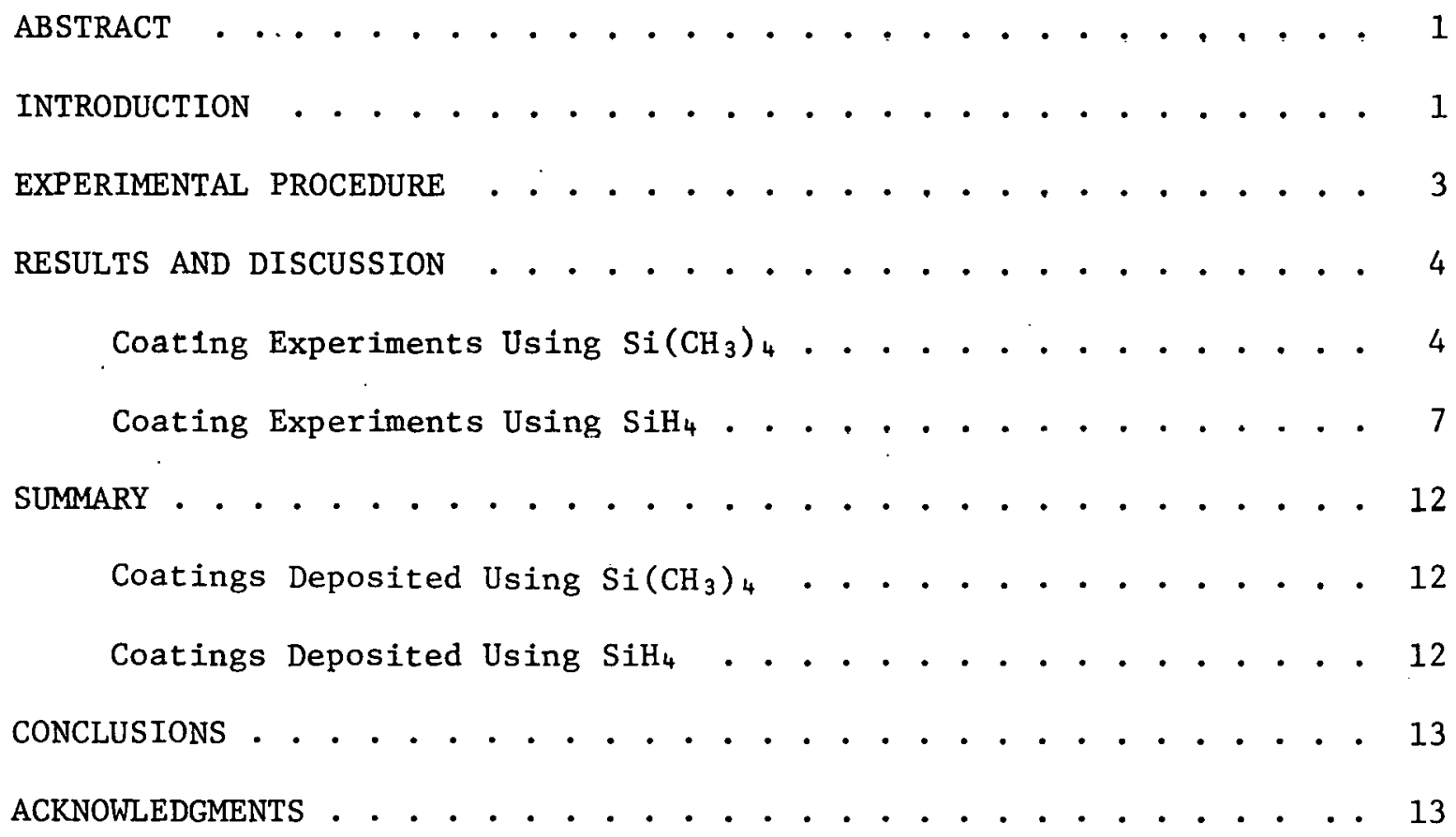

This report was prepared as an account of work This report was prepared as an Gavernment. Neither the United Stotes nor the United States Department of

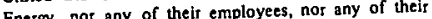
Energy, con any wan ex sompleteness labliny or res ar infor ar issefind

process disclosed, or represents that in
infringe privately owned rights. 


\title{
DEPOSITION OF SILICON CARBIDE COATINGS QN PARTICLES IN A FLUIDIZED BED USING SILANE AND TETRAMETHYLSILANE - A FEASIBILITY STUDY
}

\section{J. I. Federer}

ABSTRACT

\begin{abstract}
Deposition of silicon carbide ( $\mathrm{SiC}$ ) coatings from compounds such as methyltrichlorosilane $\left(\mathrm{CH}_{3} \mathrm{SiCl}_{3}\right)$ results in corrosive chlorine-containing by-products. The feasibility of depositing coatings from silane $\left(\mathrm{SiH}_{4}\right)$ and tetramethylsilane $\left[\mathrm{Si}\left(\mathrm{CH}_{3}\right)_{4}\right]$, which contain no chlorine, was briefly studied. Coatings of $\mathrm{SiC}$ were deposited from $\mathrm{Si}\left(\mathrm{CH}_{3}\right)_{4}$ over the temperature range 1025 to $1525^{\circ} \mathrm{C}$ in beds of particles fluidized with either $\mathrm{H}_{2}$ or $\mathrm{Ar}$. The densest coatings were deposited at $1025^{\circ} \mathrm{C}$, but none approached the theoretical density of SiC. A SiC coating was also deposited at $800^{\circ} \mathrm{C}$ from a mixture of $\mathrm{SiH}_{4}$, $\mathrm{C}_{2} \mathrm{H}_{4}$, and $\mathrm{H}_{2}$.
\end{abstract}

\section{INTRODUCTION}

The purpose of the silicon carbide ( $\mathrm{SiC}$ ) coating on High-Temperature Gas-Cooled Reactor (HTGR) nuclear fuel particles is to prevent diffusion of fission products to the surface of the particle during service at high temperatures. The coating is typically deposited in a fluidized bed of particles using methyltrichlorosilane $\left(\mathrm{CH}_{3} \mathrm{SiCl}_{3}\right.$, or MTS) as the source gas and hydrogen as the fluidlzing gas.' 'lhis source gas is easily vaporized (bp $66.4^{\circ} \mathrm{C}$ ), contains silicon and carbon in stolchiometric proportion for $\mathrm{SiC}$, and decomposes readily in the presence of hydrogen to form SiC. The disadvantages with MTS are the large amount and corrosive nature of the $\mathrm{HCl}$ and other chlorine-containing by-products. A commercial coating operation would require scrubbers and neutralizers to treat the exhaust gases, adding conslderably to capital and maintenance

\footnotetext{
${ }^{1} \mathrm{~J}$. I. Federer, Fluidized Bed Deposition and Evaluation of Silicon Carbide Coatings on Microspheres, ORNL/TM-5152 (January 1977).
} 
costs. A source compound containing less chlorine than MTS would alleviate this if the SiC coating were comparable in quality to that deposited from MTS.

Compounds that might be used to deposit SiC are shown in Table 1, wherein MTS is also included for comparison. No compounds containing oxygen or fluorine are included. 'l'he presence of oxygen might result in deposition of oxides, while the presence of fluorine would result in formation of by-products more corrosive than those formed by compounds containing chlorine. The compoundo in Table 1 offer a variety of volatilities, r./Si ratios, and Cl/Si ratios. The most interesting of these are $\mathrm{SiH}_{4}, \mathrm{SiH}_{3} \mathrm{CH}_{3}, \mathrm{SiH}_{2}\left(\mathrm{CH}_{3}\right)_{2}, \mathrm{SI}_{2}\left(\mathrm{CH}_{3}\right)_{6}, \mathrm{Si}\left(\mathrm{CH}_{3}\right)_{4}, \mathrm{CH}_{3} \mathrm{SiH}_{2} \mathrm{C} 1$, and $\left(\mathrm{CH}_{3}\right)_{3} \mathrm{SiCH}_{2} \mathrm{Cl}$. Five of these contain no chlorine, while two have a $\mathrm{Cl} / \mathrm{Si}$ ratio of one compared with a ratio of three for MTS. Except for $\mathrm{SiH}_{4}$, all contain carbon, although not always in stoichiometric proportion. for SiC.

Table 1. Possible Source Compounds for Deposition of SiC

\begin{tabular}{|c|c|c|c|}
\hline Compound & $\begin{array}{l}\text { Rniling } \\
\text { Point } \\
\left({ }^{\circ} \mathrm{C}\right)\end{array}$ & $\begin{array}{l}\text { C/S1 } \\
\text { Ratio }\end{array}$ & $\begin{array}{l}\text { C1/Ei } \\
\text { Ratio }\end{array}$ \\
\hline Silicun tetrachloride, $\mathrm{SiCl}_{4}$ & 57.6 & 0 & 4 \\
\hline Dichlorusilane, $\mathrm{H}_{2} \mathrm{SiCl}_{2}$ & 8.2 & 0 & 2 \\
\hline Silane, $\mathrm{SiH}_{4}$ & -111.8 & 0 & 0 \\
\hline Methyltrlchlurosilane, $\mathrm{CH}_{3} \mathrm{SiCl}_{3}$ & 66.4 & 1 & 3 \\
\hline Methyldirhlorosilane, $\mathrm{CH}_{3} \mathrm{SiHCl}_{2}$ & 41.5 & 1 & 2 \\
\hline Methychlorosilane, $\mathrm{CH}_{3} \mathrm{SiH}_{2} \mathrm{Cl}$ & 1 & 1 & 1 \\
\hline Methylsilane, $\mathrm{SiH}_{3} \mathrm{CH}_{3}$ & 31 & 1 & 0 \\
\hline $\begin{array}{l}\text { Dimethyldichlorosilane, } \\
\left(\mathrm{CH}_{3}\right)_{2} \mathrm{SiCl}_{2}\end{array}$ & 70.5 & 2 & 2 \\
\hline Dimethyl sillane, $\mathrm{SiH}_{2}\left(\mathrm{CH}_{3}\right)_{2}$ & -20.1 & 2 & 0 \\
\hline $\begin{array}{l}\text { Methylvinyldichlorosilane, } \\
\qquad \mathrm{CH}_{3}\left(\mathrm{C}_{2} \mathrm{H}_{3}\right) \mathrm{SiCl}_{2}\end{array}$ & 92.9 & 3 & 2 \\
\hline Hexamethylstlane, $\mathrm{Si}_{2}\left(\mathrm{CH}_{3}\right)_{6}$ & 112.5 & 3 & 0 \\
\hline $\begin{array}{l}\text { Trimethylchloromethylstlane, } \\
\left(\mathrm{CH}_{3}\right)_{3} \mathrm{Si}_{\mathrm{CH}} \mathrm{Cl}\end{array}$ & 97.1 & 4 & 1 \\
\hline Tetramethylsilane, $\mathrm{Si}\left(\mathrm{CH}_{3}\right)_{4}$ & 26.5 & 4 & 0 \\
\hline
\end{tabular}


Commercial sources for some of these compounds could not be found. Two compounds, silane $\left(\mathrm{SiH}_{4}\right)$ and tetramethylsilane $\left[\mathrm{Si}\left(\mathrm{CH}_{3}\right)_{4}\right]$, were available for use in this study. Others would have been used had time permitted. The feasibility of depositing $\mathrm{SiC}$ using $\mathrm{SiH}_{4}$ and $\mathrm{Si}\left(\mathrm{CH}_{3}\right)_{4}$ has been assessed by conducting deposition experiments over a range of temperatures. The resulting deposits were evaluated principally by $x$-ray diffraction and ceramographic examination.

\section{EXPERIMENTAL PROCEDURE}

The apparatus used in previous work ${ }^{1}$ to deposit SiC coatings from MTS is shown in Fig. 1. This apparatus, modified as described below, was also used in the present study. When used in previous work, the reservoir was heated to vaporize MTS, and the vapor was carried by a stream of hydrogen into the fluidized bed. In the present work the reservoir was filled with $\mathrm{Si}\left(\mathrm{CH}_{3}\right)_{4}$ instead of MTS, and the vapor was transported in the same manner as for MTS. When using $\mathrm{SiH}_{4}$ from a cylinder of compressed gas (not shown in Fig. 1), the vapor generator

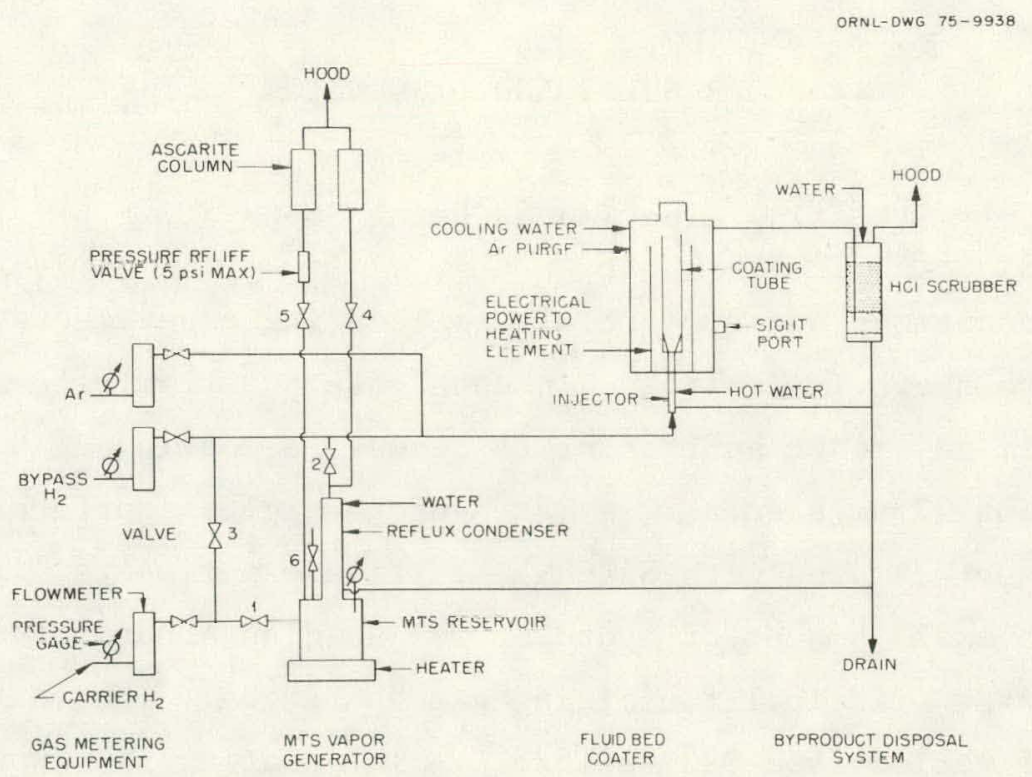

Fig. 1. Fluidized Bed Coating System. The system was slightly modified for depositing $\mathrm{SiC}$ from $\mathrm{Si}\left(\mathrm{CH}_{3}\right)_{4}$ and $\mathrm{SiH}_{4}$ instead of MTS. 
was simply bypassed. The HCl scrubber, which is required for MTS, was not used for either $\mathrm{SiH}_{4}$ or $\mathrm{Si}\left(\mathrm{CH}_{3}\right)_{4}$. Instead, the exhaust gases bypassed the scrubber (bypass not shown in Fig. 1) and were burned in a hood.

Fluidized beds were obtained in a 25-mm-ID graphite tube with a $36^{\circ}$-included-angle cone. The particles to be coated, which consisted of $\mathrm{ThO}_{2}$ kernels with two layers of pyrocarbon (PyC), had an average diameter of about $475 \mathrm{\mu m}$, d density of about $2.44 \mathrm{Mg} / \mathrm{m}^{3}$, and a specific surface area of ahnut $5.2 \mathrm{~m}^{2} / \mathrm{kg}$. Either 10 ur $20-\mathrm{g}$ batches were coated. All coating experiments were conducted at a system pressure of about $0.1 \mathrm{MPa}$. The temperature was measured by an optical pyrometer sighted on the coating tube wall at about the junction of tube and cone. The pyrometer reading was corrected for the silica glass sight port.

The $\mathrm{SiH}_{4}$ was metered with a rotameter-type flowmeter. Since the flowmeter was calibrated for air at about $25^{\circ} \mathrm{C}$, a correction factor based on the density of $\mathrm{SiH}_{4}$ was applied to the flowmeter reading. The $\mathrm{Si}\left(\mathrm{CH}_{3}\right)_{4}$ was transferred in a metered stream of $\mathrm{H}_{2}$, the flow rate of $\mathrm{Si}\left(\mathrm{CH}_{3}\right)_{4}$ having been previously determined by condensing and weighing the vapor.

\section{RESULTS AND DISCUSSION}

\section{Coating Experiments Using $\mathrm{Si}\left(\mathrm{CH}_{3}\right)_{4}$}

The conditions and some results of coating experiments using $\mathrm{Si}\left(\mathrm{CH}_{3}\right)_{4}$ are shown in Table 2 . In each case the flow rate of $\mathrm{Si}_{\left(\mathrm{CI}_{3}\right)_{4}}$ was $13 \mathrm{mg} / \mathrm{s}$, an amount suffirient to deposit a coating at a theoretical rate of about $17 \mathrm{im} / \mathrm{s}$ on a $20-\mathrm{g}$ balch of particles (surface area $\approx 0.104 \mathrm{~m}^{2}$ ). Only hydrogen was used with $\mathrm{Si}\left(\mathrm{CH}_{3}\right)_{4}$ in five experiments. In the other four only a small amount of hydrogen was used as a carricr for $\mathrm{Si}\left(\mathrm{CH}_{3}\right)_{4}$ vapur, and the principal fluidizing gas was argon. The coating temperature varied from 825 to $1525^{\circ} \mathrm{C}$. The coating time was $1.8 \mathrm{ks}$ in each case. 
Table 2. Conditions and Results of Coating Experiments Using $\mathrm{Si}\left(\mathrm{CH}_{3}\right)_{4}{ }^{\mathrm{a}}$

\begin{tabular}{|c|c|c|c|c|c|c|c|}
\hline \multicolumn{2}{|c|}{ Flow Rate, $\mathrm{cm}^{3} / \mathrm{s}$} & \multirow{2}{*}{$\begin{array}{c}\text { Temperature } \\
\left({ }^{\circ} \mathrm{C}\right)\end{array}$} & \multicolumn{2}{|c|}{$\begin{array}{c}\text { Particle Density, } \\
\mathrm{Mg} / \mathrm{m}^{3}\end{array}$} & \multirow{2}{*}{$\begin{array}{l}\text { Coating } \\
\text { Weight } \\
\text { (g) }\end{array}$} & \multirow{2}{*}{$\frac{\mathrm{X}-\text { Ray }}{\mathrm{PyC}^{\mathrm{C}}}$} & \multirow{2}{*}{$\frac{\text { Intensity }^{b}}{\beta-S i C^{d}}$} \\
\hline $\mathrm{H}_{2}$ & Ar & & $\begin{array}{l}\text { Before } \\
\text { Coating }\end{array}$ & $\begin{array}{l}\text { After } \\
\text { Coating }\end{array}$ & & & \\
\hline 50 & 0 & 825 & 2.41 & 2.41 & 0 & & \\
\hline 50 & 0 & 1025 & 2.41 & 2.41 & 3.94 & $\mathrm{~S}_{+}$ & $\mathrm{W}^{\mathrm{c}}$ \\
\hline 50 & 0 & 1125 & 2.41 & 1.97 & 9.85 & $\mathrm{M}^{+}$ & $\mathrm{s}^{\mathrm{c}}$ \\
\hline 50 & 0 & 1225 & 2.44 & 1.61 & 7.48 & $\mathrm{M}$ & $S^{c}$ \\
\hline 50 & 0 & 1525 & 2.44 & 1.17 & 14.50 & M & $S$ \\
\hline 2 & 25 & 1025 & 2.39 & 2.42 & 5.35 & & $\mathrm{~W}_{\mathrm{C}}^{-\mathrm{C}}$ \\
\hline $\begin{array}{l}2 \\
2\end{array}$ & $\begin{array}{l}25 \\
25\end{array}$ & $\begin{array}{l}1125 \\
1225\end{array}$ & $\begin{array}{l}2.43 \\
2.44\end{array}$ & $\begin{array}{l}2.06 \\
1.50\end{array}$ & $\begin{array}{l}11.95 \\
16.85\end{array}$ & $\begin{array}{l}\mathrm{W} \\
\mathrm{M}\end{array}$ & $\mathrm{S}^{\mathrm{c}}$ \\
\hline 2 & 25 & 1525 & 2.44 & 1.70 & 12.58 & $\mathrm{~S}$ & $\mathrm{~S}$ \\
\hline
\end{tabular}

${ }^{a}$ In all cases, the $\mathrm{Si}\left(\mathrm{CH}_{3}\right)_{4}$ flow rate was $13 \mathrm{mg} / \mathrm{s}$ and the surface area of the particles being coated was $0.104 \mathrm{~m}^{2}$. W-weak.

${ }^{b}$ Intensity estimated from diffractometer traces: S-strong, M-medium,

${ }^{c_{P y C}}$ in the SiC coating, if present, could not be distinguished from the underlying layer of PyC.

$\mathrm{d}_{\text {Broad peaks. }}$

The particle densities shown in Table 2 were calculated from the weight and "tapped" volume. ${ }^{2}$ The tapped volume was adjusted to the true volume by using the packing fraction for spheres of 0.62 . In the five experiments using hydrogen as the fluidizing gas, the particle density after coating decreased with increasing deposition temperature, indicating that the coating was less dense than the original particle $\left(\sim 2.4 \mathrm{Mg} / \mathrm{m}^{3}\right)$ and, therefore, much less dense than SiC (theoretical density $3.210 \mathrm{Mg} / \mathrm{m}^{3}$ ). Coatings deposited with argon as the fluidizing gas behaved similarly to those deposited with hydrogen.

Table 2 indicates that the weights of coatings deposited with hydrogen varied somewhat erratically with increasing temperature, whereas those of coatings deposited with argon exhibited a maximum as a function of deposition temperature. Deposition of all the silicon as SiC in the metered $\mathrm{Si}\left(\mathrm{CH}_{3}\right)_{4}$ would have resulted in a coating weight of $10.9 \mathrm{~g}$. Since the weight of some coatings exceeded $10.9 \mathrm{~g}$, and since $\mathrm{Si}\left(\mathrm{CH}_{3}\right)_{4}$

${ }^{2}$ The "tapped" volume was obtained by tapping a graduated cyclindes containing the particles with a commercially obtained device until closest packing of the particles was achieved. 
contains excess carbon over that required for stoichiometric SiC, the coatings probably contained excess carbon. Decomposition of $\mathrm{Si}\left(\mathrm{CH}_{3}\right)_{4}$ to $\mathrm{SiC}$ and by-products requires that $\mathrm{C}-\mathrm{H}$ bonds be broken. Hydrogen would be expected to suppress breaking of $\mathrm{C}-\mathrm{H}$ bonds, thereby suppressing carbon deposition. Decomposition of $\mathrm{Si}\left(\mathrm{CH}_{3}\right)_{4}$ in an argon atomosphere should be less likely to suppress deposition of carbon; however, essentially the same results were obtained with either hydrogen or argon used as the prinripal fluidizing gas.

The presence of excess carbon in some of the coatings was inferred from the coating weights, but was not proven by x-ray diffraction of either whole particles or coating fragments. In the case of whole particles, $x$-ray diffraction cannot distinguish between PyC in the SiC coating and the underlying layers of PyC, which werc part of the original particle. On the other hand, when coating fragments were heated in air to burn away adhering PyC layers, x-ray diffraction revealed only SiC and $\mathrm{SiO}_{2}$. Of course, any $\mathrm{PyC}$ in the coating might also have burned away, so x-ray evidence of PyC could not be expected, and none was obtained. Table 2 shows that $\beta$-SiC was deposited at each temperature. The $\mathrm{x}$-ray diffractometer pallesus of coatinge depnsiter at $1025^{\circ} \mathrm{C}$ had very broad peaks, indicaling either an amorphnus character ui small crysta11ites. Rroad peaks persisted to $1225^{\circ} \mathrm{C}$, but the crystalline perfection was better at $1525^{\circ} \mathrm{C}$. Nevertheless, these experiments have demonstrated the feasibility of depositing $\mathrm{SiC}$ from $\mathrm{Si}\left(\mathrm{CH}_{3}\right)_{4}$ at temperatures as 1 ow as $1025^{\circ} \mathrm{C}$.

Polished sections of the coatings are shown in Fig. 2. The vuler coatings deposited from either carrier gas at $1025^{\circ} \mathrm{C}$ appear to be single phase and denser than the underlying PyC layer; however, these coatings always contained radial cracks. At higher depositinn temperatures the outer coatings are much thicker relative to the coating deposited at $1025^{\circ} \mathrm{C}$ and appear to contain more than one phase and/or porosity. Gross purosity is shown in most cases by intrusion of the ceramographic mounting material into the coatings.

The density of coatings is usually determined with a liquid density gradient column by procedures described elsewhere. ${ }^{1}$ The coating fragments for determination of density are obtained by breaking the coated 

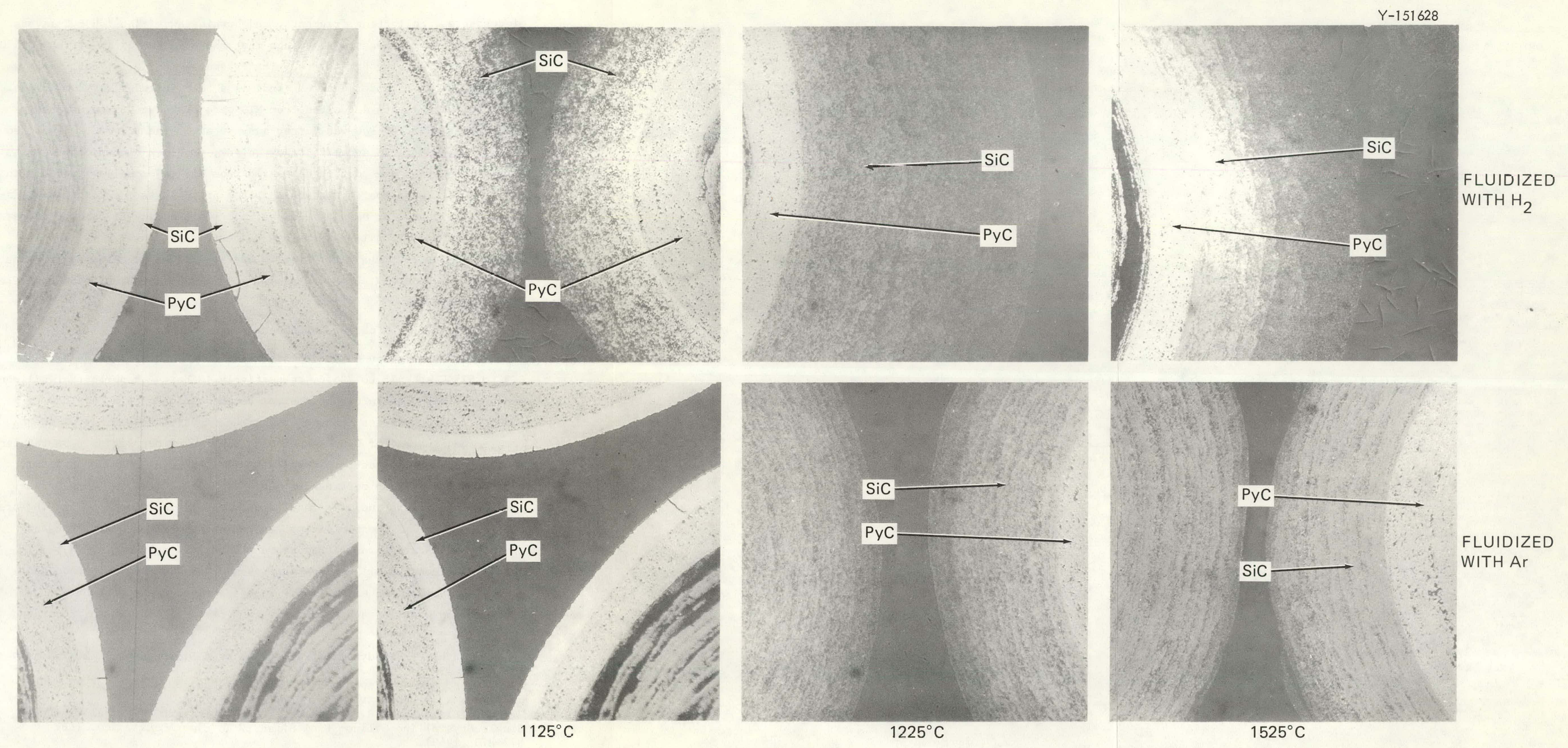
microspheres, collecting fragments, and burning away adhering PyC layers. Figure 3 shows fragments of coatings that had been heated in air at $1000^{\circ} \mathrm{C}$ to burn away adhering PyC layers. The fragments in the top row, which were deposited from MTS under optimum conditions, are included for comparison. The coating fragments deposited from MTS were translucent and uniformly green after adhering PyC was burned away in air. The fragments deposited from $\mathrm{Si}\left(\mathrm{CH}_{3}\right)_{4}$ at 1025 and $1125^{\circ} \mathrm{C}$ were black, or black and white, after burning. Whereas the coating deposited from MTS wrs anmletely stable in air at $1000^{\circ} \mathrm{C}$, the coatings deposited from Si( $\left(\mathrm{CH}_{3}\right)_{1}$ were subject to nxida tion, as evidenced by a white residue, and the tendency to oxidize increased with increasing deposition temperature (decreasing density). The white residue in the coatings after burning was identified by $x$-ray diffraction as $\mathrm{SiO}_{2}$. The coating deposited at 1225 and $1525^{\circ} \mathrm{C}$ appeared to be completely oxidized to $\mathrm{SiO}_{2}$.

Coating Experiments Using $\mathrm{SiH}_{4}$

Silane has been used to deposit $\mathrm{Si}_{3} \mathrm{~N}_{4}$ and $\mathrm{SiO}_{2}$ coatings on wafers at 675 to $825^{\circ} \mathrm{C}$ and 475 to $725^{\circ} \mathrm{C}$, respectively. ${ }^{3}$ Barry ${ }^{4}$ reports that silicon can he depnsited on wafero by thermal decumpusiliun of $\mathrm{SiH}_{4}$ at 1000 to $1050^{\circ} \mathrm{C}$. Since hydrngen tends to retard dccomposition of $\mathrm{SiH}_{4}$, an inert carrier gas instead of hydrogen should allow lower deposition temperatures to be used, and, in fact, this was demonstrated by Richman and Arlett, ${ }^{5}$ who deposited silicon coatings at $800^{\circ} \mathrm{C}$ using helium as the carrier gas. The conditions and some results of coating experiments using $\mathrm{Sill}_{4}$ die shown in Table 3. The fluidizing gas was either hydrogen or argon, and the soulce of carbon was elther propene $\left(\mathrm{C}_{3} \mathrm{H}_{6}\right)$ or acetylene $\left(\mathrm{C}_{2} \mathrm{H}_{2}\right)$. In three experiments a silicon coating was desired, sn no hydrocarbon gas was used. A $10-\mathrm{g}$ bed of particles wilh a surfacc area of about $0.052 \mathrm{~m}^{2}$ was used in each case. The flow rates of $\mathrm{SiH}_{4}$ and hydrocarbons

\footnotetext{
${ }^{3}$ G. Wahl, "Hydrodynamic Description of CVD Processes," Thi. . Soli.d Films 40: 13-26 (1977).

${ }^{4}$ B. E. Barry, "Vapour Phase Growth of Semiconducting Layers," Thin Solid Films 39: 35-53 (1977).

${ }^{5}$ D. Richman and R. H. Arlett, "Low-Temperature Epitaxial Growth of Single Crystalline Silicon From Silane," J. Electrochem. Soc. 116: 872-873 (1969).
} 
$\mathrm{H}_{2}+\mathrm{CH}_{3} \mathrm{SiCl}_{3}$

$\mathrm{H}_{2}+\mathrm{Si}\left(\mathrm{CH}_{3}\right)_{4}$
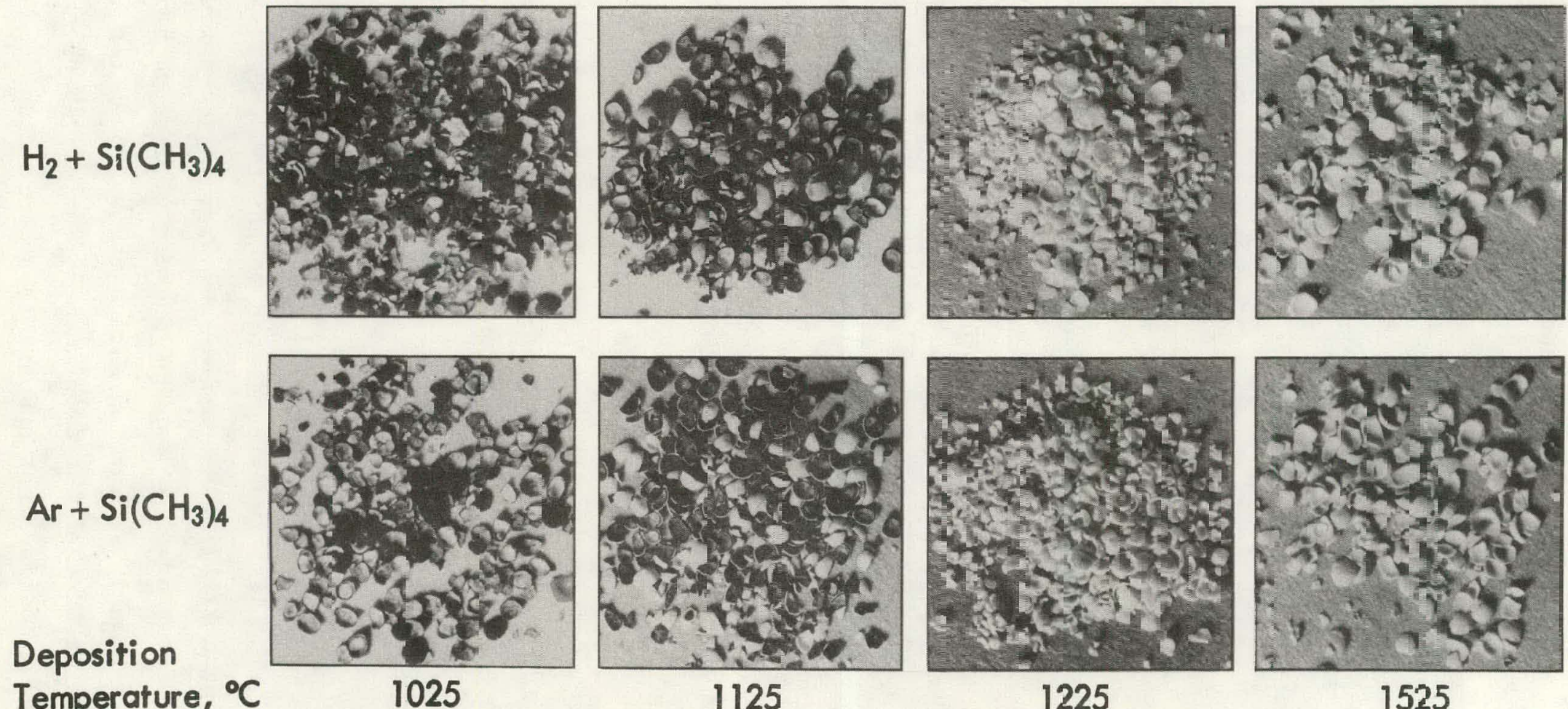

1225

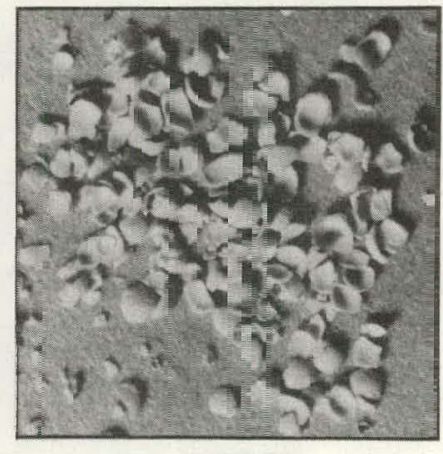

1525

Fig. 3. Fragments of Coatings Deposited from $\mathrm{S} \dot{-}\left(\mathrm{CH}_{3}\right)_{4}$ after Heating in Air at $1000^{\circ} \mathrm{C}$ for $2 \mathrm{hr}$. 
Table 3. Conditions and Results of Coating

Experiments Using $\mathrm{SiH}_{4}$

\begin{tabular}{|c|c|c|c|c|c|}
\hline & low & ate, & $\mathrm{cm}^{3} / \mathrm{s}$ & Temperature & \\
\hline $\mathrm{SiH}_{4}$ & $\mathrm{H}_{2}$ & Ar & Hydrocarbon & $\left({ }^{\circ} \mathrm{C}\right)$ & \\
\hline 1.5 & 0 & 7 & $0.5^{\mathrm{a}}$ & 1300 & Fluidization stopped in $<60 \mathrm{~s}$. \\
\hline 1.5 & 0 & 7 & $0.5^{a}$ & 1200 & Fluidization stopped in $<60 \mathrm{~s}$. \\
\hline 0.5 & 0 & 7 & $0.5^{a}$ & 1300 & Fluidization stopped in $<60 \mathrm{~s}$. \\
\hline 0.5 & 25 & 0 & 0 & 1000 & $\begin{array}{l}\text { Brown, powdery coating identified as } \\
\text { silicon by x-ray diffrartinn. }\end{array}$ \\
\hline 0.5 & 35 & 0 & 0 & 800 & $\begin{array}{l}\text { Adherent coating on particles identified } \\
\text { as silicul by x-ray diffraction. }\end{array}$ \\
\hline 0.5 & $\hat{u}$ & 25 & & $8(x)$ & Fluidization stopped in $ح 900 \mathrm{~s}$. \\
\hline 0.5 & 35 & 0 & $0.3_{\mathrm{h}}^{\mathrm{b}}$ & 800 & Fluidization stopped in $<30 \mathrm{~s}$. \\
\hline 0.5 & 60 & 0 & $0.3^{b}$ & 800 & $\begin{array}{l}\text { Adherent coating on particles shown by } \\
\text { x-ray diffraction to be SiC. }\end{array}$ \\
\hline
\end{tabular}

were sufficient to deposit $\mathrm{SiC}$ at theoretical rates of about 5 to $17 \mathrm{~nm} / \mathrm{s}$ if all the silicon were deposited as stoichiometric SiC.

The first three experiments shown in Table 3 used $3: 1$ and $1: 1$ mixtures of $\mathrm{SiH}_{4}$ and $\mathrm{C}_{3} \mathrm{H}_{6}$ in beds fluidized with argon at 1200 and $1300^{\circ} \mathrm{C}$. Each time tluidization stopped within $60 \mathrm{~s}$ of admission of $\mathrm{SiH}_{4}$ and $\mathrm{C}_{3} \mathrm{H}_{6}$. The $\mathrm{SiH}_{4}$ apparently decomposed so rapidly that a solid mass formed at the entrance to the fluidized bed.

Hydrogen was then used as the fluidizing gas in an attempt to retard decomposition of $\mathrm{SiH}_{4}$. A hydrocarbon gas was not used in these experiments. At $1000^{\circ} \mathrm{C}$ a brown, powdery silicon coating was obtained on the particles and the coating tube wall, but at $800^{\circ} \mathrm{C}$ an adherent silicon coating was obtained on the particles. Figure 4 shows polished cross sections through several particles coated at $800^{\circ} \mathrm{C}$. A metallic-like coating with a rough surface is revealed. When argon was substituted for hydrogen at $800^{\circ} \mathrm{C}$ the bed ceased to be fluidized after about $900 \mathrm{~s}$.

The last two experiments sought to deposit a SiC coating at $800^{\circ} \mathrm{C}$ using a 2:1 mixture of $\mathrm{Sill}_{4}$ and $\mathrm{C}_{2} \mathrm{H}_{2}$ in a bed fluidized with hydrogen. The first of these was not successful because fluidization stopped in less than $30 \mathrm{~s}$, but increasing the hydrogen resulted in an adherent coating in the last experiment. The polished cross sections in Fig. 5 show a coating that appears to be more dense than the underlying PyC 


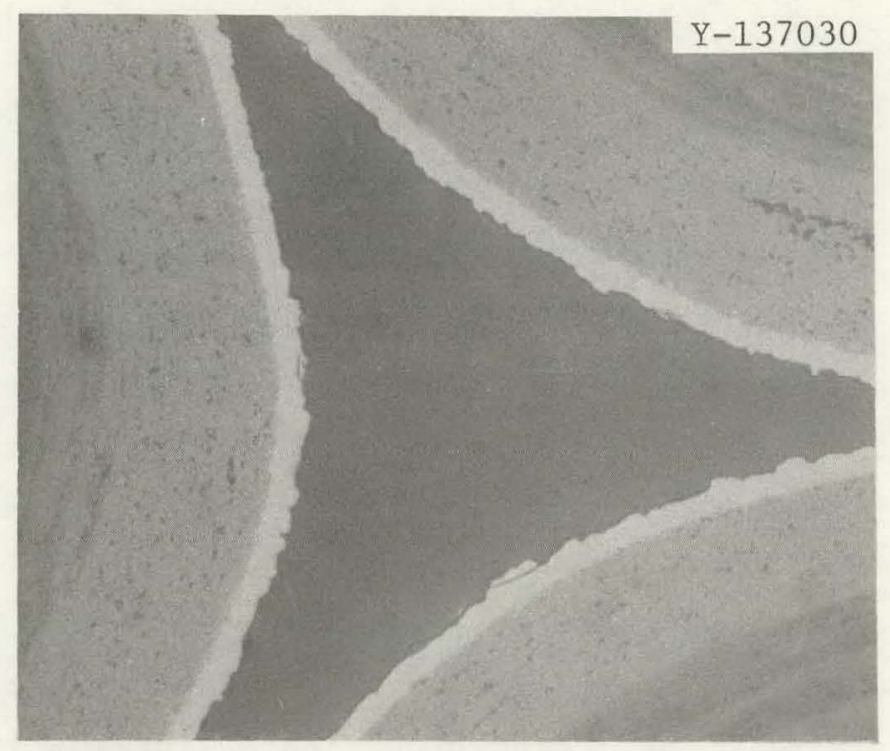

Fig. 4. Silicon Coating Deposited at $800^{\circ} \mathrm{C}$ from a Mixture of $\mathrm{SiH}_{4}$ and $\mathrm{H}_{2}$. As polished. 400x.

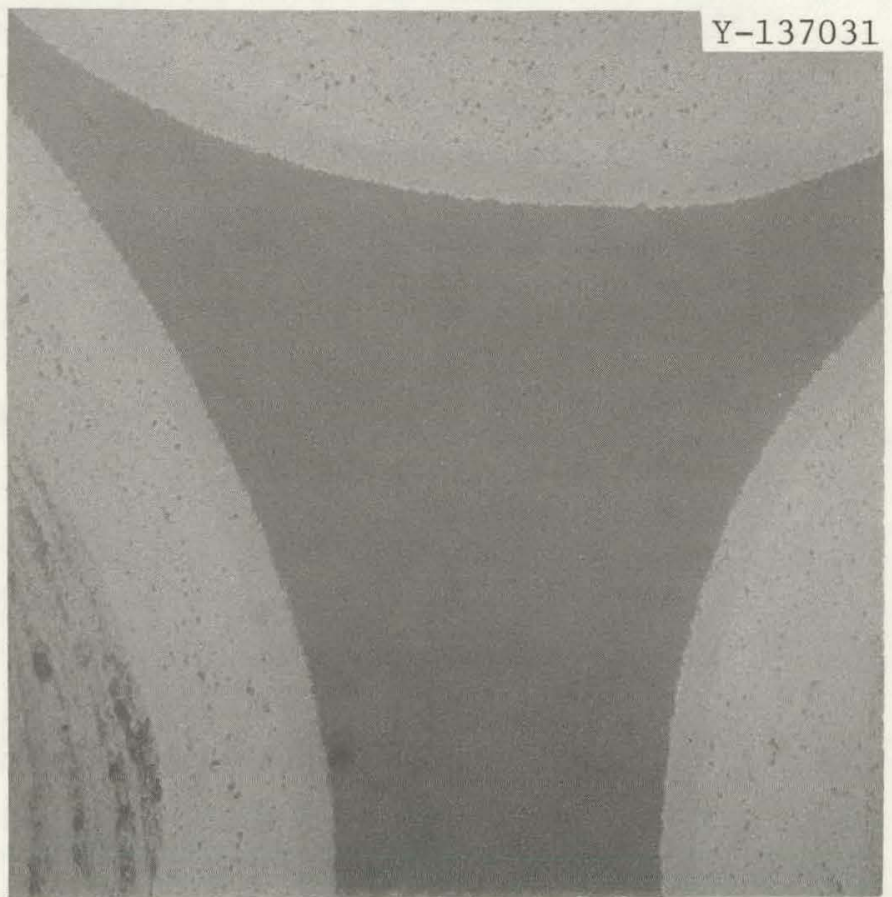

Fig. 5. SiC Coating Deposited at $800^{\circ} \mathrm{C}$ from a Mixture of $\mathrm{SiH}_{4}$, $\mathrm{C}_{2} \mathrm{H}_{2}$ and $\mathrm{H}_{2}$. As polished. 400x. 
layer; however, the coating contains porosity and has a rough surface. The coating was identified as $\beta$-SiC by $x$-ray diffraction. The $x$-ray pattern had very broad peaks, indicating either an amorphous character or small crystallites.

SUMMARY

Coatings Deposited Using $\mathrm{Si}\left(\mathrm{CH}_{3}\right)_{4}$

1. When hydrogen was used as the fluidizing gas, the amount of deposited material varied erratically with increasing temperature in the range 800 to $1500^{\circ} \mathrm{C}$. With argon the deposited weight exhibited a maximum in the same temperature range.

2. The density of particles after coating was the same as or lower than the density before coating, indicating that the coating density never exceeded $2.4 \mathrm{Mg} / \mathrm{m}^{3}$, the density of the original particles. The density of the coatings never approached the theoretical density of $\operatorname{SiC}\left(3.210 \mathrm{Mg} / \mathrm{m}^{3}\right)$.

3. Fragments of coatings heated at $1000^{\circ} \mathrm{C}$ in air oxidized partly or completely to $\mathrm{SiO}_{2}$.

4. Ceramographic examination showed that the densest coatings, deposited at $1025^{\circ} \mathrm{C}$ with either hydrogen or argon, contained radial cracks, while the less dense coatings contained gross porosity.

5. X-ray diffraction revealed that each coating was at least partly SiC; however, the coatings were poorly crystalline, as evidenced by line broadening on the diffraction patterns. The crystallinity of coatings deposited at $1523^{\circ} \mathrm{C}$ was best.

\section{Coatings Deposited Using SiII}

The few experiments that have been performed indicate that a large amount of hydrogen is required to suppress the decomposition of $\mathrm{SiH}_{4}$ to silicon and hydrogen in a fluidized bed. A SiC coating was deposited with a mixture of $\mathrm{SiH}_{4}$ and $\mathrm{C}_{2} \mathrm{H}_{2}$ at $800^{\circ} \mathrm{C}$. Deposition from $\mathrm{SiH}_{4}$ and $\mathrm{C}_{3} \mathrm{H}_{6}$ in beds fluidized with argon at 1200 and $1300^{\circ} \mathrm{C}$ was unsuccessful because of formation of a solid mass at the entrance to the fluidized 
bed within only $60 \mathrm{~s}$. Better success with $\mathrm{SiH}_{4}$ and $\mathrm{C}_{3} \mathrm{H}_{6}$ might have been obtained at lower temperatures but no such tests were tried.

\section{CONCLUSIONS}

This study has shown the feasibility of depositing SiC coatings on particles in a fluidized bed from either tetramethylsilane [ $\mathrm{Si}_{\left.\left(\mathrm{CH}_{3}\right)_{4}\right]}$ or silane $\left(\mathrm{S}_{4} \mathrm{H}_{4}\right)$, thereby avuiding the corrosive by-product gases associated with coatings deposited from such compounds as methyltrichlorosilane $\left(\mathrm{CH}_{3} \mathrm{SiCl}_{3}\right.$ or MTS). However, no coatings were deposited that had both high density and structural integrity. Much additional work would be required to achieve highly dense, stoichiometric coatings. This work shows that a potential advantage in using compounds such as $\mathrm{Si}\left(\mathrm{CH}_{3}\right)_{4}$ and $\mathrm{SiH}_{4}$ is the deposition of $\mathrm{SiC}$ coatings at temperatures of 800 to $1000^{\circ} \mathrm{C}$ rather than about $1500^{\circ} \mathrm{C}$, as often used for MTS.

\section{ACKNOWLEDGMENTS}

The author wishes to acknowledge the assistance of others in the performance of this work: J. W. Geer, deposition of coatings and other experimental work; W. H. Warwick, ceramography; O. B. Cavin, x-ray diffraction; J M Robbins and J. A. Carpenter, review of the manuscript; and S. Peterson, editing, and K. A. Witherspoon, typing and preparation of this report. 
THIS PAGE

\section{WAS INTENTIONALLY LEFT BLANK}


ORNL/TM-6185

Distribution

Category UC-77

\section{INTERNAL DISTRIBUTION}

1-2. Central Research Library

3. Document Reference Section

4-23. Laboratory Records Department

24. Laboratory Records, ORNL RC.

25. ORNL Patent office

26. R. L. Beatty

27. R. A. Bradley

28. A. J. Caputo

29. J. A. Carpenter, Jr.

30. J. A. Conlin

31. J. H. Coobs

32. R. S. Crouse

33. W. P. Eatherly

34-43. J. I. Federer

44. T. G. Godfrey

45. R. L. Heestand
46-48. M. R. Hill
19. J. D. Holder
50. F. J. Homan
51. D. R. Johnson
52-53. P. R. Kasten
54. R. K. Kibbe
55. W. J. Lackey
56. J. S. Lin
57. E. L. Long, Jr.
58. A. L. Lotts
59. M. T. Morgan
60. A. R. Olsen
61. A. E. Pasto
62. H. Postma
63. G. W. Scott
64. D. P. Stinton
65. T. N. Tiegs

EXTERNAL DISTRIBUTION

66-67. DOE DIVISION OF REACTOR NUCLEAR RESEARCH AND APPLICATIONS Washington, DC 20545

Director

68. DOE IDAHO OPERATIONS OFFICE, P.0. Box 2108, Idaho Falls, ID $83 / 01$

Barry Smith

69. DOE OFFICE OF PROGRAM MANAGEMENT, RESEARCH AND SPACE PROGRAMS,

P. 0. Box 81325, San Diego, CA 92138

J. B. Radcliffe

70. DOE SAN FRANCIEGO OPERATIONS OFFICE, 1333 Broadway, We1ls Fargo

Building, Oakland, CA 94612

Manager

71-73, DOE OAK RIDGE OPERATIONS OFFICE, P.O. Box E, Oak Ridge, TN 37830

Director, Research and Technical Support Division

Director, Reactor Division

F. E. Dearing, Reactor Division 
74-250. DOE TECHNICAL INFORMATION CENTER, P.0. Box 62, Oak Ridge, TN 37830

For distribution as shown in TID-4500 Distribution

Category, UC-77 (Gas-Cooled Reactor Technology)

251-258. ERDA Exchange Agreements with Germany and Dragon Project 